\title{
The effect of combination of sugarcane pressmud compost and potassium fertilizer on vegetative growth of corn in coastal sandy soil
}

\author{
Budiyanto, G. \\ Faculty of Agriculture, Universitas Muhammadiyah Yogyakarta, Jl. Brawijaya, Tamantirto, Daerah \\ Istimewa Yogyakarta 55183, Indonesia
}

\begin{abstract}
Article history:
Received: 5 November 2020

Received in revised form: 12

December 2020

Accepted: 16 February 2021

Available Online: 13 June

2021
\end{abstract}

Keywords:

Low content of soil moisture and potassium,

Sugarcane press mud

compost,

Slow-release fertilizer

DOI:

https://doi.org/10.26656/fr.2017.5(3).630

\begin{abstract}
Generally, coastal sandy soil has low water content and potassium nutrients. One way to fix this is by adding organic matter and potassium fertilizers. Sugarcane press mud compost as organic material acts as a slow-release fertilizer, it has an effect long enough to support plant growth. A pot experiment was carried out to test the probability of combining sugarcane press mud compost and potassium fertilizer to improve the vegetative growth of corn plants in coastal sandy soils. This research was arranged in a factorial completely randomized design. The first factor is the dosages of sugarcane press mud compost $(0,20,25,30,35$ tons per hectare). The second factor is the dosages of potassium fertilizer $\left(0,60,90\right.$, and $120 \mathrm{~kg} \mathrm{~K}_{2} \mathrm{O}$ per hectare). After applying basal fertilizer (120 kg N per hectare and $90 \mathrm{~kg}_{2} \mathrm{O}_{5}$ per hectare) and the treatment factor has been applied, the corn seed is planted and grown until vegetative growth or at flowering. The results showed that sugarcane press mud compost and potassium fertilizer interacted with the effect of shoots fresh and dry weight, fresh weight, and root dry weight. The combination treatment of 25 tons of sugarcane press mud compost per hectare and $90 \mathrm{~kg}$ $\mathrm{K}_{2} \mathrm{O}$ per hectare (B2P2) resulted in the highest fresh weight and dry weight of shoots. Meanwhile, the combination of 0 tons of sugarcane press mud compost per hectare and $120 \mathrm{~kg} \mathrm{~K} 2 \mathrm{O}$ per hectare (B0P3) produced the highest fresh weight and plant roots' dry weight. The two treatments did not interact in influencing plant height and potassium content in the corn leaf tissue. Both the sugarcane press mud treatment (20, 25, 30 and 35 tons per hectare), and the application of potassium fertilizer (60 and $90 \mathrm{~kg} \mathrm{~K} \mathrm{~K}_{2} \mathrm{O}$ per hectare) significantly increased plant height growth. The highest dosage of sugarcane press mud compost (35 tons per hectare) and potassium fertilizer (120 $\mathrm{kg} \mathrm{K}_{2} \mathrm{O}$ per hectare) produces potassium content in plant leaf tissue.
\end{abstract}

\section{Introduction}

Coastal sandy soil has potential to be utilized in the biomass production process. In general, the volume space of coastal sandy soil is dominated by the sand fraction. The soil texture ranges between sandy and loamy and does not form soil aggregates (Bruand et al., 2005). One of the problems of coastal sandy soil is that it has a low capacity to store water, low content of clay minerals, organic matter, and nutrients (Ismail and Ozawa, 2006; Slavich et al., 2010). The limitation of coastal sandy soil, which does not form soil aggregates, causes this soil to have a high leaching capacity so that most of the nutrients can move downward through gravity water. Pathan et al. (2003) stated that this high leaching capacity is due to the high hydraulic conductivity which contributes to large amounts of water passing beyond the root zone of plants.

Potassium is an element that plants need, and is absorbed in the form of positive ions. This potassium ion can be stored in the soil colloid complex, which is negatively charged. In general, soil fertility is influenced by soil colloid complexes composed of clay and organic matter interactions. Coastal sandy soil does not have quality colloid qualities due to its low content of clay mineral and organic matter so that its potassium nutrient content is low. Potassium fertilization is not efficient because potassium will be leached out of the sandy soil (Erickson et al., 2005). The research results by Kayser et al. (2012) found that the leaching process of potassium nutrients in sandy soils will increase in parallel with the leaching process of nitro-nitrogen elements. Based on this, the use of coastal sandy soil as agricultural land 
must improve the soil's physical properties so that its water-binding capacity increases and potassium nutrients can be stored in the root zone. One way that is worth trying is the addition of organic matter to improve soil infiltration quality. The application of organic matter into sandy soil has been shown to improve soil chemical properties, especially potassium availability (Hamed et al., 2011).

One source of organic material that can be used to improve coastal sandy soil's physical properties is sugarcane press mud, which is a waste processing sugarcane stalks into sugar. This organic waste has a high nutrient and carbon content so that it has the potential to increase soil humus. According to Kumar et al. (2017), sugarcane press, a form of bioproduct, has great potential to be used as an organic fertilizer, improving soil health and sustainable agronomic productivity. The composition of the nutrient content in this material varies from one sugar factory to another. The difference in nutrient content is influenced by the sugarcane variety and the soil type. According to Supari et al. (2015), sugar cane factory waste in the form of bagasse contains a complete element as an organic fertilizer. The nutrient content is organic-C $(9.93 \%)$, total $-\mathrm{N}(1.13 \%), \mathrm{N}^{-\mathrm{NH}_{4}}(0.50 \%), \mathrm{N}-\mathrm{NO}_{3}(0.11 \%), \mathrm{C} / \mathrm{N}$ ratio (8.76), $\mathrm{P}_{2} \mathrm{O}_{5}$ (1.05\%), $\mathrm{K}_{2} \mathrm{O}$ (0.16 ppm), $\mathrm{Fe}(10,308.67$ ppm), $\mathrm{Mn}$ (758,597 ppm), $\mathrm{Cu}(50.75 \mathrm{ppm})$ and $\mathrm{Zn}(90.68$ $\mathrm{ppm})$. The nutrient content of sugarcane press mud in vegetable cultivation has been shown to increase yield. The experimental results of Halifah et al. (2014) proved that giving composted sugarcane bagasse can increase the weight of plant biomass and tuber weight.

Increasing soil productivity with the sand fraction's dominance can be done by adding materials that can create a soil colloid system. Materials that can be used are clay minerals, sources of organic matter, or a combination of both. The application of organic fertilizers into sandy soil that has been carried out by Ellmer and Baumecker (2008) proves that the use of organic fertilizers can increase the organic-C content compared to crop rotation. Tahir and Marschner (2017) experimented by adding clay minerals into sandy soil. The experimental results proved that the addition of 10 $20 \%$ clay minerals per soil weight could reduce $\mathrm{N}$ and $\mathrm{P}$ elements' leaching in sandy soils. Djajadi et al. (2011) also proved that the application of a combination of organic matter and clay particles could improve soil aggregate stability, total porosity, and water availability. Senjobi et al. (2013) have increased sandy soil productivity using organic matter and mineral fertilizers. The experiment results proved that four kinds of chicken manure, cow manure, Gateway fertilizer, and organo- mineral fertilizers combined with NPK fertilizer significantly increased the productivity of sandy soil.

Sugar press mud or sugarcane filter-cake is waste from the sugar industry (Diaz, 2016). This material is in the form of a blackish-brown solid with a high enough fiber content. This material can be used as a source of organic matter to increase the productivity of coastal sandy soils. This study is aimed to examine the potential of sugarcane press mud compost as organic compost and its combination with potassium fertilizer to increase corn plants' growth in coastal sandy soils.

\section{Materials and methods}

The sandy soil used in this research is taken from Trisik beach Kulonprogo, Yogyakarta. Sugarcane press mud compost is taken from the waste processing plant area of the Madukisma sugar factory. CP-II Hybrid corn seeds and inorganic fertilizers are obtained from agricultural shops in Yogyakarta.

This research was conducted using experimental methods arranged in a factorial, completely randomized design. The first factor was the application of sugarcane press mud at a dose of 0 ton per hectare (B0); 20 tons per hectare (B1); 25 tons per hectare (B2); 30 tons per hectare (B3), and 35 tons per hectare (B4). The second treatment factor was the dose of potassium fertilizer, 0 $\mathrm{kg} \mathrm{K}_{2} \mathrm{O}$ per hectare (P0); $60 \mathrm{~kg} \mathrm{~K}_{2} \mathrm{O}$ per hectare (P1); 90 $\mathrm{kg} \mathrm{K} \mathrm{K}_{2} \mathrm{O}$ per hectare $(\mathrm{P} 2)$, and $120 \mathrm{~kg} \mathrm{~K}_{2} \mathrm{O}$ per hectare (P3). Each treatment combination was repeated six times in order to obtain 120 experimental units. The coastal sandy soil samples from each experimental unit $(7,512 \mathrm{~g}$ air-dried) were put into a polybag with a perforated bottom, mixed with sugarcane press mud according to the treatment dose, then incubated for one month under conditions of field capacity moisture. Basic fertilizer treatment $\left(120 \mathrm{~kg} \mathrm{~N}\right.$ per hectare and $90 \mathrm{~kg} \mathrm{P}_{2} \mathrm{O}_{5}$ per hectare) and potassium fertilizer treatment were applied after the incubation period was completed. Corn planting is carried out after fertilizer application, and corn plants are grown until the maximum vegetative period, or the plants reach the flowering stage.

Analysis of the soil properties of coastal sandy soil was carried out before the experiment and after the experiment to determine the effect of sugarcane press mud application on coastal sandy soil properties. Analysis of sugarcane press mud properties was carried out to determine the potential properties of sugarcane press mud compost in improving coastal sandy soil's productivity. After the plants reach the flowering period, measurements of the parameters of plant height, fresh weight and dry weight of the vegetative part of the plant 
without roots (shoots), fresh weight and dry weight of root and the content of potassium in leaf tissue, as well as the content of $\mathrm{K}$-total, $\mathrm{K}$-available, are measured. $\mathrm{C} / \mathrm{N}$ ratio and soil $\mathrm{pH}$ of the used planting media. All data were analyzed for variance using SAS version 20.0.15, and to differentiate the mean of the treatments that were significantly different, tested Duncan's Multiple Range at $5 \%$.

\section{Results and discussion}

Coastal sandy soil is unproductive soil with low fertility. The results of determining the potential for soil fertility are shown in Table 1.

Table 1. The characteristics of coastal sandy soil

\begin{tabular}{lc}
\hline \multicolumn{1}{c}{ Soil characteristics } & Value \\
\hline Moisture content (\%) & 0.18 \\
Sand (\%) & 97.20 \\
Silt (\%) & 2.10 \\
Clay (\%) & 0.70 \\
Specific gravity $\left(\mathrm{g} / \mathrm{cm}^{3}\right)$ & 2.39 \\
Bulk density $\left(\mathrm{g} / \mathrm{cm}^{3}\right)$ & 1.58 \\
Soil porosity $(\%)$ & 33.89 \\
pH $(1: 2.5)$ & 6.80 \\
Organic-C (\%) & 0.12 \\
Total-N (\%) & 0.00 \\
C/N ratio & 30.00 \\
Available-P (Olsen, me/100 g)) & 2.56 \\
CEC (me/100 g) & 3.60 \\
Total-K (\%) & 0.01 \\
Available-K (me/100 g) & 0.04 \\
Humic acid (\%) & 0.08 \\
Fulvic acid (\%) & 0.03 \\
Na (me/100 g) & 0.16 \\
Ca (me/100 g) & 0.82 \\
Mg (me/100 g) & 0.37 \\
\hline
\end{tabular}

From Table 1, it is known that coastal sandy soil is dominated by a fraction of sand $(97.2 \%)$, dust $(2.10 \%)$, clay minerals $(0.70 \%)$, and low organic-C $(0.12 \%)$. As a result of the low clay mineral content and organic matter, this soil does not form aggregates and has a soil porosity of $33.89 \%$, so it has low water retention with $0.18 \%$ soil moisture content. The potential for soil chemical fertility is also low, nitrogen content $(0.004 \%)$, available-P $(2.560 \mathrm{me} / 100 \mathrm{~g})$, total-K $(0.012 \%), \mathrm{Na}(0.163 \mathrm{me} / 100$ $\mathrm{g})), \mathrm{Ca}(0.82 \mathrm{me} / 100 \mathrm{~g})$ and $\mathrm{Mg}(0.37 \%)$. In addition to low nitrogen content, potassium content is also low and is the main problem that sandy soils have; as Alshankiti and Gill (2016) stated, sandy soils generally have low nutrient content and low water storage capacity. According to Budiyanto et al. (2020), the available-K content of Parangtritis beach sandy soil was $24.07 \mathrm{mg} /$ $\mathrm{kg}$, while research by Minhal et al. (2020) found that the available-K content of the sandy soils at Samas beach in Yogyakarta was $3.1 \mathrm{mmol} / \mathrm{kg}$.

The properties of sugarcane press mud are determined to know the potential of this material in improving coastal sandy soil properties. The results of determining the properties of sugarcane press mud are shown in Table 2.

Table 2. The characteristics of sugarcane press mud

\begin{tabular}{lc}
\hline \multicolumn{1}{c}{ Characteristics } & Value \\
\hline Moisture content (\%) & 9.38 \\
Organic-C (\%) & 18.77 \\
Total-N (\%) & 1.18 \\
$\mathrm{pH}(1: 2.5)$ & 7.30 \\
$\mathrm{C} / \mathrm{N}$ ratio & 15.00 \\
Humic acid (\%) & 3.29 \\
Fulvic acid (\%) & 3.63 \\
CEC (me/100 g) & 37.32 \\
Total-K (\%) & 1.21 \\
Available-K (me/100 g) & 14.26 \\
\hline
\end{tabular}

Sugarcane press mud is an organic material that is hydrophilic and can store more water than sandy soil. This material has a water content of $9.38 \%$, so with its amorphous form, this material can increase coastal sandy soil's ability to store water. The content of several elements and their compounds, such as organic-C (18.77\%), humic acid (3.29\%), and fulvic acid (3.73\%), are thought to support the formation of colloid complexes of coastal sandy soil. The cation exchange capacity is $37.32 \mathrm{me} / 100 \mathrm{~g}$ and available-K 14.26 $\mathrm{me} / 100 \mathrm{~g}$, indicating that this material can increase coastal sandy soils' productivity. Sugarcane press mud is an organic material that can function as a source of organic fertilizer. In many countries, sugar factory waste compost has been used to increase soil fertility, plant productivity, accelerate the soil restoration process, suitable for use in the agricultural, horticulture, and aquaculture industries (Salehe-In et al., 2012). This material contains lots of nutrients, cellulose, hemicellulose, organic carbon fiber, nitrogen, phosphorus, potassium, magnesium, calcium, and several microelements such as $\mathrm{Zn}, \mathrm{Fe}, \mathrm{Cu}$, and $\mathrm{Mn}$ (Krishnaveni et al., 2020). Sugarcane press mud compost contains many macro and microelements needed by plants, and in many practices, it is often mixed with other organic fertilizer sources (Diaz, 2016).

Measurement of the vegetative growth parameter of corn was carried out when the plants reached the flowering period. The measurement results are intended to determine the effect of various doses of sugarcane press mud and potassium fertilizer applications, as 
shown in Table 3.

Table 3 shows that the treatment of sugarcane press mud and potassium fertilizer did not influence plant height growth. The application of sugarcane press mud and potassium fertilizer separately significantly affected corn's height growth. Sugarcane press mud treatment can provide nutrient needs such as corn plant growth. Application of sugarcane press mud compost of 20 ton per hectare separately can provide potassium for the corn's growth. The dose of 20 tons of sugarcane press mud per hectare has the same effect as other dosages. Meanwhile, the application of $60 \mathrm{~kg} \mathrm{~K}_{2} \mathrm{O}$ per hectare resulted in the highest plant growth and was not significantly different from the effect of 90 ton $\mathrm{K}_{2} \mathrm{O}$ per hectare.

On the other hand, the treatment of sugarcane press mud and potassium fertilizer interacted in influencing the fresh weight and dry weight of shoots. The combination of sugarcane press mud treatment and potassium fertilizer affected the plant roots' fresh weight and dry weight. The combination treatment of 25 tons of sugarcane press mud compost per hectare (B2) and $90 \mathrm{~kg}$ $\mathrm{K}_{2} \mathrm{O}$ per hectare (P2) produced the largest fresh weight and dry weight of shoots. Meanwhile, the combination of 0 tons of sugarcane press mud compost per hectare (B0) and $120 \mathrm{~kg} \mathrm{~K}_{2} \mathrm{O}$ per hectare (P3) produced the largest fresh weight and plant roots' dry weight. Plant shoots' growth is supported by the accumulation of potassium preparations from both sugarcane press mud compost and potassium fertilizer. The combination of organic matter treatment and inorganic fertilizers is the right method to increase coastal sandy soil's productivity (Nuga and Akinbola, 2011; Orimoloye et al., 2019). On the other hand, the need for potassium for plant root development is mostly provided by inorganic fertilizers, which are faster to release the nutrient content of potassium.

Table 3. The vegetative performance of corn at the flowering stage

\begin{tabular}{|c|c|c|c|c|c|}
\hline Treatments & $\begin{array}{l}\text { Plant height } \\
\text { (cm) }\end{array}$ & $\begin{array}{c}\text { Fresh weight of } \\
\text { shoots }(\mathrm{g})\end{array}$ & $\begin{array}{l}\text { Dry weight of } \\
\text { shoots }(\mathrm{g})\end{array}$ & $\begin{array}{l}\text { Fresh weight of } \\
\operatorname{root}(\mathrm{g})\end{array}$ & $\begin{array}{l}\text { Dry weight of } \\
\text { root }(\mathrm{g})\end{array}$ \\
\hline $\mathrm{BO}$ & $162.38^{\mathrm{b}}$ & 170.40 & 24.32 & 105.82 & 14.99 \\
\hline B1 & $197.26^{\mathrm{a}}$ & 246.60 & 34.14 & 107.18 & 15.06 \\
\hline $\mathrm{B} 2$ & $204.88^{\mathrm{a}}$ & 282.95 & 40.49 & 118.84 & 16.98 \\
\hline B3 & $194.12^{\mathrm{a}}$ & 244.75 & 34.95 & 104.88 & 13.94 \\
\hline B4 & $196.82^{\mathrm{a}}$ & 258.78 & 38.23 & 107.08 & 15.42 \\
\hline $\mathrm{P} 0$ & $182.16^{\mathrm{q}}$ & 211.68 & 32.93 & 95.54 & 14.80 \\
\hline $\mathrm{P} 1$ & $199.78^{p}$ & 242.03 & 33.48 & 92.68 & 12.94 \\
\hline $\mathrm{P} 2$ & $196.48^{p}$ & 258.58 & 39.47 & 121.22 & 17.68 \\
\hline P3 & $185.98^{q}$ & 250.35 & 31.82 & 125.62 & 15.98 \\
\hline B0P0 & 134.52 & $60.62^{\mathrm{g}}$ & $9.16^{\mathrm{f}}$ & $19.56^{\mathrm{d}}$ & $2.95^{\mathrm{f}}$ \\
\hline B0P1 & 175.52 & $183.55^{\mathrm{f}}$ & $26.72^{\mathrm{e}}$ & $92.22^{\mathrm{bc}}$ & $13.38^{\text {bcde }}$ \\
\hline B0P2 & 171.62 & $196.44^{\mathrm{ef}}$ & $30.76 b^{\text {cde }}$ & $132.90^{\mathrm{ab}}$ & $20.95^{\mathrm{ab}}$ \\
\hline B0P3 & 164.88 & $240.38^{\text {bcde }}$ & $30.66^{\text {bcde }}$ & $177.60^{\mathrm{a}}$ & $22.68^{\mathrm{a}}$ \\
\hline $\mathrm{B} 1 \mathrm{P} 0$ & 198.86 & $268.48^{\mathrm{abc}}$ & $41.14^{\mathrm{abc}}$ & $134.24^{\mathrm{ab}}$ & $20.56^{\mathrm{abc}}$ \\
\hline $\mathrm{B} 1 \mathrm{P} 1$ & 208.32 & $231.98^{\text {cde }}$ & $26.88^{\text {de }}$ & $70.74^{\mathrm{c}}$ & $8.20^{\mathrm{ef}}$ \\
\hline $\mathrm{B} 1 \mathrm{P} 2$ & 196.60 & $271.94^{\mathrm{abc}}$ & $40.08^{\mathrm{abc}}$ & $117.88^{\mathrm{c}}$ & $17.35^{\mathrm{abcd}}$ \\
\hline $\mathrm{B} 1 \mathrm{P} 3$ & 182.90 & $214.24^{\mathrm{def}}$ & $28.48^{\text {sde }}$ & $105.90^{\mathrm{bc}}$ & $14.10^{\text {bcde }}$ \\
\hline $\mathrm{B} 2 \mathrm{P} 0$ & 194.52 & $255.08^{\mathrm{bcd}}$ & $39.58^{\mathrm{abc}}$ & $99.50^{\mathrm{bc}}$ & $15.28^{\text {abcde }}$ \\
\hline $\mathrm{B} 2 \mathrm{P} 1$ & 216.22 & $287.92^{\mathrm{ab}}$ & $39.44^{\mathrm{abcd}}$ & $117.90^{\mathrm{bc}}$ & $16.18^{\text {abcde }}$ \\
\hline $\mathrm{B} 2 \mathrm{P} 2$ & 211.54 & $310.62^{\mathrm{a}}$ & $46.46^{\mathrm{a}}$ & $137.24^{\mathrm{ab}}$ & $20.50^{\mathrm{abc}}$ \\
\hline $\mathrm{B} 2 \mathrm{P} 3$ & 195.28 & $278.18^{\mathrm{abc}}$ & $36.54^{\text {abcde }}$ & $121.50^{\mathrm{bc}}$ & $15.98^{\text {abcde }}$ \\
\hline B3P0 & 192.20 & $235.04^{\text {bcde }}$ & $30.65^{\text {bcde }}$ & $108.35^{b c}$ & $14.58^{\text {bcde }}$ \\
\hline B3P1 & 195.54 & $253.48^{\mathrm{bcd}}$ & $38.04^{\text {abcde }}$ & $80.68^{\mathrm{bc}}$ & $12.10^{\mathrm{de}}$ \\
\hline B3P2 & 201.90 & $241.57^{\text {bcde }}$ & $36.80^{\text {abcde }}$ & $121.60^{\mathrm{bc}}$ & $14.38^{\text {bcde }}$ \\
\hline B3P3 & 188.20 & $248.90^{\mathrm{bcd}}$ & $33.34^{\text {bcde }}$ & $108.90^{\mathrm{bc}}$ & $14.58^{\text {bcde }}$ \\
\hline $\mathrm{B} 4 \mathrm{P} 0$ & 190.88 & $239.24^{\text {bcde }}$ & $43.14^{\mathrm{ab}}$ & $117.05^{\mathrm{bc}}$ & $21.15^{\mathrm{ab}}$ \\
\hline $\mathrm{B} 4 \mathrm{P} 1$ & 196.24 & $252.90^{\mathrm{bcd}}$ & $36.42^{\text {abcde }}$ & $101.80^{\mathrm{bc}}$ & $14.68^{\text {bcde }}$ \\
\hline $\mathrm{B} 4 \mathrm{P} 2$ & 200.78 & $272.20^{\mathrm{abc}}$ & $43.28^{\mathrm{ab}}$ & $95.52^{\mathrm{bc}}$ & $15.18^{\text {abcde }}$ \\
\hline B4P3 & 198.36 & $270.74^{\mathrm{abc}}$ & $30.14^{\text {cde }}$ & $113.90^{\mathrm{bc}}$ & $12.68^{\text {cde }}$ \\
\hline
\end{tabular}

Values are expressed as mean. Values with the same superscript within the column are not significantly different based on Duncan's multiple range test at $5 \%$. 
Sugarcane press mud compost, which is applied as organic fertilizer, can improve sandy soil's physical fertility to increase its water-binding ability. Organic fertilizers can significantly improve soil structure and nutrient availability (Hoa et al., 2010; Badar et al., 2018). Increasing the availability of water in the root zone can support the K-fertilizer nutrient uptake process. Sugarcane press mud compost is also thought to improve the soil colloid complex so that positively charged nutrient ions of potassium can be bound in it, and the leaching process of potassium nutrients can be reduced. The application of sugarcane press mud compost can also provide potassium nutrients from the decomposition of sugarcane press mud. The use of organic matter in sandy soil has been shown to improve the quality of plant growth (Hou et al., 2013). Applying organic fertilizers in sandy soil can significantly increase all growth parameters of plants growing in sandy soil. Experiments conducted by Zeid et al. (2015) proved that the use of various kinds of organic fertilizers could increase plant height, shoot weight, tuber weight, and leaf tissue nutrient content when compared to control treatments. While the research results of Darini et al. (2016) proved that organic matter affects the chemical properties of coastal sandy soil.

The effect of applying sugarcane press mud treatment and potassium fertilizer on potassium's nutrient status in the soil is essential to study. Table 4 presents the analysis of some of the characteristics of the used planting media.

Table 4 shows that the treatment of sugarcane press mud and potassium fertilizer did not affect the $\mathrm{C} / \mathrm{N}$ ratio of sandy soil, but separately, each treatment affected the $\mathrm{C} / \mathrm{N}$ ratio. Duncan's multiple range test of 5\% showed that the application of sugarcane press mud compost could reduce the $\mathrm{C} / \mathrm{N}$ ratio. There are assumptions that the $\mathrm{C} / \mathrm{N}$ ratio of sugarcane press mud can affect the $\mathrm{C} / \mathrm{N}$ ratio of sandy soil. Meanwhile, increasing the dose of potassium fertilizer tends to increase the $\mathrm{C} / \mathrm{N}$ ratio. Analysis of variants of the total potassium content in the soil used for planting media showed an interaction between the sugarcane press mud treatment and potassium fertilizer. Duncan's multiple distance test of $5 \%$ shows that the combined treatment of 30 tons of sugarcane press mud per hectare and $120 \mathrm{~kg} \mathrm{~K}_{2} \mathrm{O}$ per hectare (B4P3) leaves the highest total potassium content in the soil used for planting media (160.28 ppm). The remaining total potassium in the soil used for planting media was not significantly different from the treatment combination of $\mathrm{B} 3 \mathrm{P} 3, \mathrm{~B} 4 \mathrm{P} 1$, and $\mathrm{B} 4 \mathrm{P} 2$. This $\mathrm{B} 4 \mathrm{P} 3$ treatment combination is a treatment that can supply the total potassium. In nutrient uptake, potassium is always balanced with nitrogen and phosphorus uptake provided by basal fertilization. After the entire potassium needs by plants can be fulfilled, this combination of treatments still leaves the total potassium.

Table 4. The characteristics of used planting media

\begin{tabular}{|c|c|c|c|c|}
\hline Treatments & $\mathrm{C} / \mathrm{N}$ ratio & $\begin{array}{l}\text { Total-K } \\
\text { (ppm) }\end{array}$ & $\begin{array}{c}\text { Available-K } \\
\text { (me/100 g) }\end{array}$ & $\mathrm{pH}$ \\
\hline B0 & $40.44^{\mathrm{a}}$ & 85.44 & $0.06^{\mathrm{c}}$ & 5.80 \\
\hline B1 & $21.12^{\mathrm{b}}$ & 94.20 & $0.09^{\mathrm{bc}}$ & 6.78 \\
\hline B2 & $21.40^{\mathrm{b}}$ & 89.34 & $0.12^{b}$ & 6.97 \\
\hline B3 & $22.20^{\mathrm{b}}$ & 114.96 & $0.10^{\mathrm{b}}$ & 7.20 \\
\hline B4 & $19.54^{\mathrm{b}}$ & 138.46 & $0.24^{\mathrm{a}}$ & 7.04 \\
\hline $\mathrm{P} 0$ & $21.15^{\mathrm{q}}$ & 94.90 & $0.06^{\mathrm{r}}$ & 6.70 \\
\hline $\mathrm{P} 1$ & $25.83^{\mathrm{pq}}$ & 97.70 & $0.12^{\mathrm{q}}$ & 6.64 \\
\hline $\mathrm{P} 2$ & $23.80^{\mathrm{pq}}$ & 110.34 & $0.14^{\mathrm{pq}}$ & 6.74 \\
\hline P3 & $29.68^{p}$ & 124.80 & $0.16^{\mathrm{p}}$ & 6.78 \\
\hline $\mathrm{B} 0 \mathrm{P0}$ & 27.12 & $108.78^{\text {cdef }}$ & 0.04 & $5.98^{d}$ \\
\hline B0P1 & 31.55 & $79.80^{\mathrm{fg}}$ & 0.03 & $5.54^{\mathrm{e}}$ \\
\hline B0P2 & 42.05 & $72.2^{\mathrm{g}}$ & 0.05 & $5.68^{\mathrm{e}}$ \\
\hline B0P3 & 59.16 & $81.28^{\mathrm{efg}}$ & 0.06 & $5.68^{e}$ \\
\hline B1P0 & 22.15 & $70.98^{\mathrm{g}}$ & 0.05 & $6.72^{c}$ \\
\hline B1P1 & 21.45 & $89.36^{\text {efg }}$ & 0.08 & $6.72^{c}$ \\
\hline $\mathrm{B} 1 \mathrm{P} 2$ & 20.38 & $88.10^{\text {efg }}$ & 0.12 & $6.75^{b c}$ \\
\hline B1P3 & 20.68 & $128.38^{b c}$ & 0.12 & $6.95^{b c}$ \\
\hline $\mathrm{B} 2 \mathrm{P} 0$ & 19.78 & $78.60^{\mathrm{fg}}$ & 0.06 & $6.90^{\mathrm{abc}}$ \\
\hline B2P1 & 28.98 & $78.50^{\mathrm{fg}}$ & 0.12 & $6.88^{\mathrm{abc}}$ \\
\hline $\mathrm{B} 2 \mathrm{P} 2$ & 14.40 & $95.60^{\text {cdefg }}$ & 0.11 & $7.05^{\mathrm{a}}$ \\
\hline B2P3 & 22.82 & $102.70^{\text {cdefg }}$ & 0.14 & $7.04^{\mathrm{a}}$ \\
\hline B3P0 & 18.42 & $92.28^{\operatorname{defg}}$ & 0.06 & $6.98^{\mathrm{a}}$ \\
\hline B3P1 & 26.82 & $97.18^{\text {cdefg }}$ & 0.10 & $7.02^{\mathrm{a}}$ \\
\hline $\mathrm{B} 3 \mathrm{P} 2$ & 21.38 & $124.12^{\text {bcd }}$ & 0.12 & $7.10^{\mathrm{a}}$ \\
\hline B3P3 & 21.88 & $144.38^{\mathrm{ab}}$ & 0.16 & $7.10^{\mathrm{a}}$ \\
\hline B4P0 & 18.50 & $113.90^{\text {bcde }}$ & 0.09 & $6.92^{\mathrm{abc}}$ \\
\hline $\mathrm{B} 4 \mathrm{P} 1$ & 18.95 & $143.80^{\mathrm{ab}}$ & 0.22 & $7.10^{\mathrm{a}}$ \\
\hline B4P2 & 21.10 & $142.94^{\mathrm{ab}}$ & 0.26 & $7.12^{\mathrm{a}}$ \\
\hline B4P3 & 19.40 & $160.28^{\mathrm{a}}$ & 0.34 & $7.10^{\mathrm{a}}$ \\
\hline
\end{tabular}

Values are expressed as mean. Values with the same superscript within the column are not significantly different based on Duncan's multiple range test at $5 \%$.

Analysis of variants on the available potassium content in the used planting media showed no interaction between sugarcane press mud treatment and potassium fertilizer. Sugarcane press mud compost is an organic fertilizer that is a slow-release nutrient, while potassium fertilizer is a fast nutrient provider. The difference in the speed of release of potassium ions causes these two treatments not to interact. Table 4 shows that sugarcane press mud compost produces the most potassium availability. The releasing potassium ions from the sugarcane press mud compost to be the highest in leaving the most available potassium in the soil used for planting media. The application of organic amendments to the sandy soil can significantly increase the available$\mathrm{K}$ and exchangeable-K. Organic amendments are suitable materials to improve soil chemical properties' 
quality and increase potassium status in sandy soils (Hamed et al., 2011). Soil fertilized with sugarcane press mud compost has higher organic content-C, N. P. K, and $\mathrm{S}$ than the soil that is not fertilized with compost (Bokhtiar et al., 2015).

The results of Duncan's 5\% multiple range test on the $\mathrm{pH}$ of the used planting media showed that the two treatments interacted. Compared with the $\mathrm{pH}$ of untreated sandy soil, the application of sugarcane press mud compost and potassium fertilizer tended to increase the soil $\mathrm{pH}$ of the used planting media.

The analysis of variance on the potassium content in the corn leaf tissue showed that the treatment of sugarcane press mud and potassium fertilizer did not interact in giving effect (Table 5).

\begin{tabular}{cccccc}
\multicolumn{6}{c}{ Table 5. The potassium content of leaf tissue of corn (\%) } \\
\hline Treatments & P0 & P1 & P2 & P3 & Average \\
\hline B0 & 0.92 & 1.12 & 1.26 & 1.54 & $1.210^{\mathrm{d}}$ \\
B1 & 1.27 & 2.14 & 2.12 & 2.16 & $1.922^{\mathrm{c}}$ \\
B2 & 1.20 & 1.94 & 2.10 & 2.26 & $1.875^{\mathrm{c}}$ \\
B3 & 1.68 & 2.10 & 2.24 & 2.34 & $2.090^{\mathrm{b}}$ \\
B4 & 1.88 & 2.38 & 2.42 & 2.71 & $2.347^{\mathrm{a}}$ \\
Average & $1.374^{\mathrm{s}}$ & $1.936^{\mathrm{r}}$ & $2.028^{\mathrm{q}}$ & $2.202^{\mathrm{p}}$ & - \\
\hline
\end{tabular}

Values are expressed as mean. Values with the same superscript within the column are not significantly different based on Duncan's multiple range test at $5 \%$.

Duncan's multiple range test of 5\% showed that the treatment of sugarcane press mud compost affected the increase in the potassium content of corn leaf tissue. The application of sugarcane press mud compost gave different effects to the potassium content in corn plants' leaf tissue. On the other hand, increasing the dose of potassium fertilizer can significantly increase the potassium content in the corn plant's leaf tissue. The content of potassium ions in the leaf tissue of this corn plant indicates that sugarcane press mud compost can be used to increase the fertility of coastal sandy soil. The utilization of sugarcane by-products in press mud and bagasse can improve the physical, biological, and soil properties and increase soil organic matter during plant growth (Dotaniya et al., 2016). Municipal solid waste compost and sugarcane press mud compost can increase and maintain soil organic matter and plant productivity (Choudhary et al., 2017). In supplying potassium nutrients during the vegetative growth of corn plants, the two treatments did not interact due to differences between them. Sugarcane press mud compost is an organic fertilizer that provides potassium nutrients slowly, while potassium fertilizer is an in-organic fertilizer that can release its nutrient content faster. However, during vegetative growth, both treatments can provide potassium nutrients for the plant.

\section{Conclusion}

Sugarcane press mud compost can be used as an organic fertilizer in coastal sandy soil. Sugarcane press mud compost and potassium fertilizer interact to affect fresh weight and dry weight of shoots, fresh weight and dry weight of roots. The combination treatment of 25 tons of sugarcane press mud compost per hectare and 90 $\mathrm{kg} \mathrm{K} 2 \mathrm{O}$ per hectare (B2P2) resulted in the highest fresh weight and dry weight of shoots. Meanwhile, the combination of 0 tons of sugarcane press mud compost per hectare and $120 \mathrm{~kg} \mathrm{~K}_{2} \mathrm{O}$ per hectare (B0P3) produced the highest fresh weight and plant roots' dry weight. The two treatments did not interact in influencing plant height and potassium content in the corn leaf tissue. Both the sugarcane press mud treatment $(20,25,30$ and 35 tons per hectare), and the application of potassium fertilizer (60 and $90 \mathrm{~kg} \mathrm{~K}_{2} \mathrm{O}$ per hectare) significantly increased plant height growth. The highest dosage of sugarcane press mud compost (35 tons per hectare) and potassium fertilizer $\left(120 \mathrm{~kg} \mathrm{~K}_{2} \mathrm{O}\right.$ per hectare) produces potassium content in plant leaf tissue.

\section{References}

Alshankiti, A. and Gill, S. (2016). Integrated Plant Nutrient Management for Sandy Soil Using Chemical Fertilizers, Compost, Biochar and Biofertilizers - Case Study in UAE. Journal of Arid Land Studies, 26(3), 101-106.

Badar, R., Rahmat, A., Fabiha, Ishtiaq, K., Mahmood, S., Zaki, S. and Bashir, Y. (2018). Recycling of organic wastes as an organic fertilizers for boosting the growth of Bengal Gram. Journal of Pharmacognosy and Phytochemistry, 7(1), 1242-1246.

Bokhtiar, S.M., Roksana, S. and Moslehuddin, A.Z.M. (2015). Soil Fertility and Productivity of Sugarcane Influenced by Enriched Pressmud Compost with Chemical Fertilizers. SAARC Journal of Agriculture, 13(2), 183-197. https://doi.org/10.3329/ sja.v13i2.26579

Bruand, A., Hartmann, C. and Lesturgez, G. (2005). Physical Properties of Tropical; Sandy Soils: A Large Range of Behaviours. In Chinabut, N. (Ed.) Management of tropical sandy soils for sustainable agriculture: a holistic approach for sustainable development of problem soils in the topics: proceedings. Bangkok: FAO.

Budiyanto, G., Aini, L.N. and Sari, S.A. (2020). Land suitability for soybean (Glycine max (L.) Merill) in sandy coastal land of Parangtritis, Bantul Regency. IOP Conference Series: Earth and Environmental 
Science, 458, 012007. https://doi.org/10.1088/17551315/458/1/012007

Choudhary, A.N., Farooq, M.S., Zeeshan, M., Khan, G., Choudary, T.K. and Abbas, M.S. (2017). Crop Yield and Soil Characteristics as Affected by Composts from Different Organic Materials with Spent Wash. Advances in Crop Science and Technology, 5(3), 16. https://doi.org/10.4172/2329-8863.1000292

Darini, M.T., Zamroni and Sunaryo, Y. (2016). Effect of Manure and Urea on Chemical Properties of Sandy Soil and Physiological Properties of Aloe Vera L. Plant Cultivated in Coastal Sandy Area. In Integrated Sci-Tech: The Interdisciplinary Research Approach, p. 211-218. Retrieved from website: http:// digilib.unila.ac.id/21632/5/BC_final_ICSTAR2015_AFC_Chapter\%2029.pdf

Diaz, P.M.N. (2016). Consequences of Compost Press Mud as Fertilizers. D.J. International Journal of Advances in Microbiology and Microbiological Research, 1(1), 28-32. https://doi.org/10.18831/ djmicro.org/2016011005

Djajadi, Heriyanto Bambang and Nurul Hidayah. (2011). Changes of Physical Properties of Sandy Soil and Growth of Physic Nut (Jatropha curca, L.) Due to Addition of Clay and Organic Matter. Journal of Agrivita, 10(3), 245-250.

Dotaniya, M.L., Darra, S.C., Baswas, D. R., Dotaniya, C. K., Meena, B.L., Rajendiran, S., Regar, K.L. and Lata, M. (2016). Use of sugarcane industrial byproducts for improving sugarcane productivity and soil health. International Journal of Recycling of Organic Waste in Agriculture, 5, 185-194. https:// doi.org/10.1007/s40093-016-0132-8

Ellmer, F. and Baumecker, M. (2008). Soil Organic Matter of a Sandy Soil Influenced by Agronomy and Climate. International Meeting in Soil Fertility, Land Management and Agroclimatology, p. 1-10. Turkey. Retrieved from website: https://core.ac.uk/download/ pdf/43801844.pdf

Erickson, J.E., Cisar, J.L., Snyder, G.H. and Volin, J.C. (2005). Phosphorus and Potassium Leaching under Contrasting Residential Landscape Models Established on a Sandy Soil. Crop Science, 45(3), 546-552. https://doi.org/10.2135/cropsci2004.0315er

Halifah, U.N., Soelistyono, R. and Santoso, M. (2014). The effect of Application of Organic Fertilizer (sugar cane filter press mud) and Inorganic Fertilizeron Shallot (Allium ascalonicum, L). Jurnal Produksi Tanaman, 2(8), 665-672.

Hamed, M.H., El-Desoky, M.A., Faragallah, M.A.A. and Usman, A.R.A. (2011). Effect of Organic Amendments on Soil Chemical Properties and
Potassium Availability to Sorghum Plants grown on a Calcareous Sandy Soil. Assiut Journal of Agricultural Sciences, 42(3), 65-76.

Hoa, H.T.H., Cong, P.T., Tam, H.M., Chen, W. and Bell, R. (2010). Sandy soils in South Central Coastal Vietnam: Their origin, constraints and management. 19th World Congress of Soil Science, Soil Solutions for a Changing World, 1 - 6 August 2010, Brisbane, Australia.

Hou, Y.H., Hu, X., Yan, W., Zhang, S. and Niu, L. (2013). Effect of organic fertilizers used in sandy soil on the growth of tomatoes. Agricultural Science, 4(5B), 31-34. https://doi.org/10.4236/ as.2013.45B006

Ismail, S.M. and Ozawa, K. (2006). Improvement of Crop Yield, Soil Moisture Distribution and Water Use Efficiency in Sandy Soils by Clay Application. Tenth International Water Technology Conference, IWTC10 2006, p. 797-811. Alexandria, Egypt.

Kayser, M., Benke, M. and Isselstein, J. (2012). Potassium Leaching Following Silage Maize on a Productive Sandy Soil. Plant, Soil and Environment, 58(12), 545-550. https://doi.org/10.17221/523/2012PSE

Krishnaveni, A., Chinnasamy, S., Elumalai, J. and Muthaiyan, P. (2020). Sugar Industry Wastes as Wealth of Organic Carbon for Soil. In Uher, I. (Ed.) Environmental Factors Affecting Human Health. InTech Open E-Book. https://doi.org/10.5772/ intechopen.90661

Kumar, S., Meena, R.S., Jinger, D., Jatav, H.S. and Banjara, T. (2017). Use of Pressmud Compost for Improving Crop Productivity and Soil Health. International Journal of Chemical Studies, 5(2), 384 -389 .

Minhal, F., Ma'as, A., Hanudin, E. and Sudira, P. (2020). Improvement of the chemical properties and buffering capacity of coastal sandy soil as affected by clay and organic by-product application. Soil and Water Research, 15(2), 93-100. https:// doi.org/10.17221/55/2019-SWR

Nuga, B.O. and Akinbola, G.E. (2011). Characteristics and Classification of Soil Developed Over Coastal Plain Sand and Shale Parent Material in Abia State Nigeria. Journal of Technology and Education in Nigeria, 16(1), 36-58.

Orimoloye, J.R., Amadi-Raphael, K.A.S. and Akinbola, G.E. (2019). Characterization and agricultural potentials of some pedons derived from sand stone parent rock near Abeokuta, Southwestern Nigeria. Journal of Soil Science and Environmental Management, 10(5), 82-93. https://doi.org/10.5897/ 
JSSEM2018.0733

Pathan, S.M., Aylmore, L.A.G. and Colmer, T.D. (2003). Soil properties and turf growth on sandy oil with fly ash. Plant and Soil, 256(1), 103-114. https:// doi.org/10.1023/A:1026203113588

Salehe-in, M.M., Yeasmin, S., Paul, B.K., Ahsan, M., Rahman, M.Z. and Roy, S.K. (2012). Chemical Studies on Press Mud: A Sugar Industries Waste in Bangladesh. Sugar Tech. An International Journal of Sugar Crops and Related Industries, 14(2), 109-118. https://doi.org/10.1007/s12355-012-0139-z

Senjobi, B.A., Akinsete, S.J., Ande O.T. and Ademoye, O.A. (2013). Sandy Soil Improvement Using Organic Materials and Mineral Fertilizer on the Yield and Quality of Jute Plant (Chorchorus Olitorius). Journal of Biology and Life Science, 4(1), 219-233. https://doi.org/10.5296/jbls.v4i1.3224

Slavich, P., Tam, H.M., Thinh, T. and Keen, B. (2010). Managing Water and Nutrients in Sandy Soils for Tree Crop Production in Central Coastal Vietnam. 19th World Congress of Soil Science, Soil Solutions for a Changing World, 1 - 6 August 2010, Brisbane, Australia.

Supari, T. and Gunawan, B. (2015). Analysis of the chemical content of organic fertilizers from sugarcane press mud from the Trangkil sugar factory. Prosiding Seminar Nasional Sains dan Teknologi. Retrieved from website: http:// publikasiilmiah.unwahas.ac.id/index.php/ PROSIDING_SNST_FT/article/view/1087

Tahir, S. and Marschner, P. (2017). Clay Addition to Sandy Soil Reduces Nutrient Leaching, Effect of Clay Concentration and Ped Size. Communication in Soil Science and Plant Analysis, 48(15), 1813-1821. https://doi.org/10.1080/00103624.2017.1395454

Zeid, H.A., Wafau, H.M., Abou El Seoud, I.I. and Alhadad, W.A.A.A. (2015). Composition and Soil Fertility of Radish Plants (Raphine's sativus) Grown in Sandy Soil. Middle East Journal of Agriculture Research, 4(1), 77-87. 